OECD Working Papers on Fiscal Federalism No. 16

\title{
Decentralisation \\ and Economic Growth - Part \\ 3: Decentralisation, \\ Infrastructure Investment \\ and Educational \\ Performance
}

Kaja Fredriksen

https://dx.doi.org/10.1787/5k4559gg7wlw-en 


\section{ABSTRACT / RÉSUMÉ \\ Decentralisation and economic growth \\ Part 3: Decentralisation, infrastructure investment and educational performance}

Theories of fiscal competition between jurisdictions suggest that investment in productive relative to consumptive spending is higher in a decentralised setting, and that efficiency of the public sector is also higher. This paper empirically analyses the link between decentralisation and the composition of public spending as well as the relation between decentralisation and educational performance. The results suggest that fiscal decentralisation increases the share of public funds directed to capital spending and that the bulk of this shift is due to higher education spending. Using an education production function approach and PISA results (Programme of International Student Assessment) as an indicator of educational output, the results suggest that educational performance is significantly higher in decentralised countries, even when controlling for spending and other variables affecting education. A 10\% point increase in decentralisation increases educational performance by four PISA points, thereby improving the PISA ranking by around four country positions on average. Decentralisation to lower government levels and decentralisation to the school level (school autonomy) have a similar impact on educational performance.

JEL classification codes: H11; H75; I22

Keywords: Fiscal decentralization; fiscal federalism; education decentralization; public investment; PISA

\section{$+++++++++++++$ \\ Décentralisation et croissance économique \\ Partie 3 : Décentralisation, investissement en infrastructure et performance des établissements scolaires}

Les théories de la concurrence budgétaire entre les pays et les entités publiques font penser que l'investissement dans les dépenses de production et non de consommation est plus élevé dans un cadre décentralisé, et que l'efficience du secteur public est supérieure également. La présente note analyse de façon empirique le lien entre décentralisation et performances des établissements scolaires. Les résultats font penser que la décentralisation budgétaire augmente la part de fonds publics axée sur les dépenses en capital, et que l'essentiel de cette évolution est dû à des dépenses dans l'éducation plus élevées. Utilisant une approche de fonction de production dans le domaine de l'éducation ainsi que les résultats du PISA (Programme d'évaluation du suivi des acquis des élèves), comme indicateurs des performances des établissements scolaires, les résultats tendent à montrer que les performances des écoles sont nettement supérieures dans les pays décentralisés, même après prise en compte des dépenses et d'autres variables influant sur l'éducation. La décentralisation à des niveaux infra-gouvernementaux et la décentralisation au niveau des écoles (autonomie des établissements scolaires) ont un impact analogue sur les performances des établissements scolaires.

Classification JEL : H11 ; H75 ; I22

Mots clés: décentralisation budgétaire; fédéralisme budgétaire; décentralisation de l'éducation ; investissement public ; PISA multimedia products in your own documents, presentations, blogs, websites and teaching materials, provided that suitable acknowledgment of OECD as source and copyright owner is given. All requests for commercial use and translation rights should be submitted to rights@oecd.org. 
TABLE OF CONTENTS

\section{DECENTRALISATION AND ECONOMIC GROWTH \\ PART 3: DECENTRALISATION, PUBLIC INVESTMENT AND EDUCATIONAL PERFORMANCE..3}

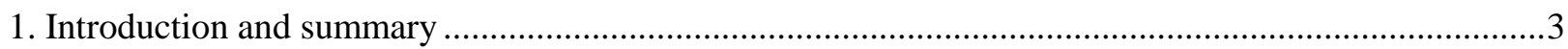

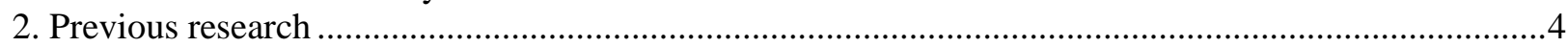

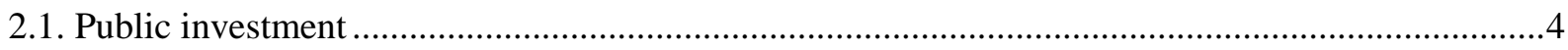

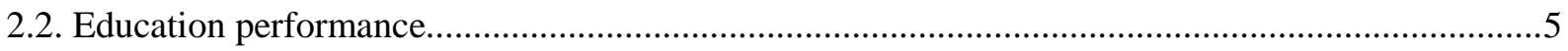

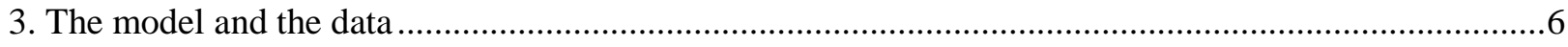

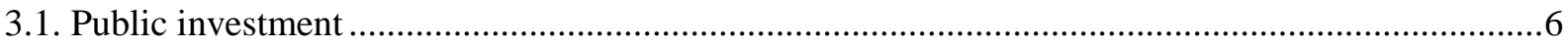

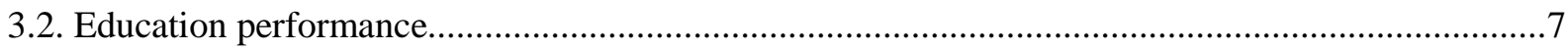

4. The impact of fiscal decentralisation on the composition of public spending .......................................9

4.1. Fiscal decentralisation is associated with higher physical and human capital spending ...................9

5. The impact of fiscal decentralisation on student performance.........................................................12

5.1. Education decentralisation improves student performance ..............................................................12

5.2. Both empowering schools and lower levels of government are beneficial ....................................14

5.3. The size of effects varies according to the type of responsibility ................................................15

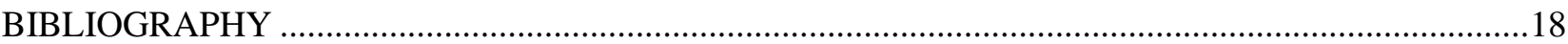

\section{Tables}

1. Decentralisation and the share of public capital and education spending .......................................10

2. Decentralisation and the share of education spending....................................................................10

3. Decentralisation and the share of public capital spending........................................................11

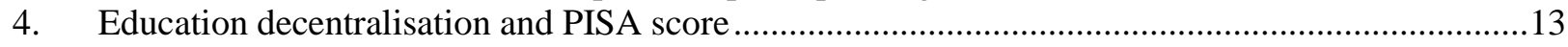

5. Education decentralisation versus fiscal decentralisation..............................................................14

6. Overall decentralisation, decentralisation to lower level of government and school autonomy .......15

7. Education decentralisation, school autonomy and PISA score....................................................15

8. Education decentralisation according to function and PISA score ..................................................17

\section{Figure}

1. Correlation between lower level government decentralisation and school autonomy .14 


\title{
DECENTRALISATION AND ECONOMIC GROWTH PART 3: DECENTRALISATION, PUBLIC INVESTMENT AND EDUCATIONAL PERFORMANCE
}

\author{
By Kaja Fredriksen ${ }^{1}$
}

\section{Introduction and summary}

This paper contains the empirical work that assesses the impact of fiscal decentralisation on the share of public investment spending as well as on educational performance. It complements and corroborates the findings on the relationship between decentralisation and growth (see Blöchliger and Égert, 2013). Since attempts to establish a link between fiscal decentralisation and economic growth deliver sometimes mixed results or are questioned on methodological grounds this paper focuses on the underlying channels through which decentralisation might affect activity. Testing the channels between fiscal decentralisation and outcomes that are more directly linked to underlying fiscal frameworks are likely to deliver more robust results. In this paper, the link between decentralisation and public investment, and the link between decentralisation and educational performance, are tested.

The main results of the empirical work are the following:

- $\quad$ Fiscal decentralisation is found to increase the combined share of physical and human capital spending regardless of the decentralisation indicator considered. On average, a $10 \%$ point increase in decentralisation increases the share of public investment in total government spending from $3 \%$ to $4 \%$.

- The effect is mainly due to spending on education. The size and significance of estimates is much higher for the relationship with education only than for the relationship with physical capital only.

- The institutional indicator for education decentralisation is significantly and positively correlated with student performance. A 10\% point increase in education decentralisation improves the PISA outcome by four points, corresponding to four positions in the country ranking. This result holds true regardless of which functions within the domain of education are devolved.

- The traditional fiscal decentralisation indicators (rather than specific education decentralisation indicators) are hardly related to educational performance. This illustrates why certain analyses require the use of more accurate policy-area-specific decentralisation indicators.

1. The author was seconded from the Norwegian Ministry of Finance to the OECD Economics Department during the time of writing this paper. I would like to thank Hansjörg Blöchliger, Balázs Égert, Jorgen Elmeskov, Peter Höller, Jean-Luc Schneider, various delegates of the Fiscal Federalism Network and the participants of an OECD seminar to whom this paper was presented. Special thanks go to Deborah Bloch and Chantal Nicq for statistical help and to Susan Gascard for excellent editorial support. 
- Decentralisation to lower government levels and decentralisation to schools (school autonomy) are substitutes. Countries with high degrees of fiscal decentralisation provide schools with little autonomy, and vice versa. Both are nevertheless conducive to student performance.

The paper is organised as follows: Section 2 summarises the results of previous studies examining the effects of decentralisation on the composition of public spending and educational performance. Section 3 lays out the model, data and estimation method used for the empirical work. To my knowledge, this is the first thorough cross-country analysis linking fiscal and regulatory autonomy of sub-central governments (SCGs) to educational performance at the national level. Sections 4 and 5 present the results.

\section{Previous research}

\subsection{Public investment}

There are different ways of conceptualising the link between fiscal decentralisation and the share of public investment. Keen and Marchand (1997) put forward the role of fiscal competition. At the heart of their model lies the assumption that local governments adjust the composition of their spending in order to attract capital. Fiscal decentralisation would therefore lead to more spending, and could even lead to overinvestment in public infrastructure (roads, sewers, etc.) and an under-investment in other public goods and services such as recreational facilities and social services. Under the efficiency hypothesis which claims that local governments produce goods and services more in line with individual preferences, the impact of fiscal decentralisation is a priori undetermined. It might be different across time and countries depending on whether the local population wants more or less public investment than is provided. The link between fiscal decentralisation and the share of public capital investment can also be influenced by budgetary procedures or the tax structure. If SCGs receive large capital grants or face a weak budget constraint on their capital expenditure, then fiscal decentralisation is more likely to favour public investment. SCGs relying on personal income taxes are likely to spend on residential rather than corporate services.

The findings by Bénassy-Quéré, et al. (2007) and Kappeler and Välilä (2007) suggest that fiscal decentralisation boosts capital spending. The former finds a shift in spending away from social expenditure towards production inputs and the latter finds that decentralisation increases economically productive investment and reduces spending on redistribution. Two separate studies conclude that decentralisation boosts spending on education. Busenmeyer (2008) finds that fiscal decentralisation affects education spending positively and public pension spending negatively, while Arze del Granado et al. (2005) find that both spending on education and health is higher at the expense of spending on pure public goods. On the other hand, Rodriguez-Pose et al. (2009), Gonzalez Alegre (2010) as well as Grisorio and Prota (2011) all find that decentralisation increases current at the expense of capital expenditure. Faguet (2004) finds that fiscal decentralisation increases investment in more socially-oriented sectors and particularly in social services and urban development. Moreover, he notes that these changes are correlated with objective indicators of need.

It is not surprising that the existing empirical literature on the impact of fiscal decentralisation on the share of public investment spending is inconclusive, given the theoretical ambiguities. The lessons that can be drawn from previous research are also limited, because there are only a few studies available. While much work has been done to evaluate the effect of fiscal decentralisation on the level of public spending, fewer tackle the implications for its composition. A last drawback is that existing studies often do not consider the same spending categories. 


\subsection{Education performance}

Proponents of decentralisation argue that lower-level governments are better informed of the local population's preferences and demands for schooling and can therefore better tailor the supply of educational services. Moreover, inter-jurisdictional competition and benchmarking might put schools under some pressure to adapt to local demands and to improve the quality of teaching. The smaller distance between those who decide on education policies and those who benefit from them is also thought to increase accountability giving lower-level governments stronger incentives to be efficient producers. Several local providers as opposed to a central one allow pupils and parents to compare school performance and demand changes if the quality of their school is deemed insufficient. On the other hand, sceptics would fear a possible loss in economies of scale from decentralisation leading to worse performance for a given input. It has also been argued that the risk of capture is greater under a decentralised scheme, and resourceful parents can lobby for policies that are beneficial for their children yet undermine average performance. It is also not clear that parents always have the necessary information to make use of broader school choice, nor that they always give priority to the quality of schools when choosing them, which undermines the competition effect from decentralisation (OECD, 2010). Lastly, decentralisation can cause harmful segregation between schools. ${ }^{2}$

Most empirical studies find a positive effect of fiscal decentralisation on educational performance. Using a panel of data on Swiss cantons (states) Barankay and Lockwood (2006) find that decentralisation in the education sector has had a positive impact on student performance. A $10 \%$ point increase in education decentralisation increases the fraction of 19-year-olds that obtain the Maturité (certificate necessary to access university) by 3.5\% points. Freinkman and Plekhanov (2009) conclude that fiscal decentralisation has a positive effect on student performance but no impact on what is generally thought to be key inputs in the education production function. ${ }^{3}$ Decentralisation thus increases productivity and this illustrates the shortcomings of only looking at effects of inputs such as teacher salaries or class size. Habibi et al. (2003) look at decentralisation and human capital development in Argentina and conclude that fiscal decentralisation has a positive effect on educational output. Sutherland and Price (2007) find that giving greater decision making autonomy to schools increases efficiency.

Previous findings also point to various factors that influence the relationship between decentralisation and performance. Barankay and Lockwood (2006) find evidence that decentralisation is more beneficial when central governments are less competent where competence is measured by the capacity to run budgetary surpluses. Using school data instead of country data the results in Sutherland and Price (2007) suggest that the final impact depends on which powers are decentralised. OECD (2010) finds that while granting schools autonomy over curricula and student assessments increases performance, this is not the case for greater responsibility in managing financial resources. ${ }^{4}$ Also, the positive effect of school autonomy appears to depend on the existence of accountability mechanisms requiring schools to publish results. Burki et al. (1999) summarise a number of studies that evaluate the effect of education decentralisation policies in Latin-America and the United States. Generally, decentralisation is found to decrease teacher absenteeism, increase attendance and reduce age-grade gaps, yet is not found to have had a consistent impact on student performance. The authors conclude that: "Taken together evaluations provide strong evidence that decentralisation can improve learning [...] those cases demonstrating the largest positive gains have emphasised school autonomy with pedagogical reform”. Akai et al. (2007)

2. Using the PISA survey, OECD (2010) finds that more school competition leads to a stronger relationship between a school's average socio-economic background and average performance.

3. Availability of computers and pre-schooling, for instance.

4. Selecting teachers for hire, establishing salaries, setting the school budget and deciding on budget allocations within the school. 
differentiate between the effects of decentralisation on performance in primary and secondary education and find positive effects for secondary education while the effects for primary education are mixed.

\section{The model and the data}

\subsection{Public investment}

The analysis will focus on the spending composition rather than spending levels since the latter is partially a question of societal choice. Both investment and consumption spending increase overall output (at least in the short run) and thereby contribute to economic activity. However, investment, both in physical and human capital, also increases GDP growth through a supply effect. More and better capital and labour input increases the productive capacity of the economy and successful R\&D investment results in higher total factor productivity. For a given level of public expenditure, most studies find that shifting public spending away from current towards investment spending is beneficial for growth (e.g. Aschauer 1989), although recent OECD research provides mixed results (Égert et al., 2009).

The empirical work is based on a model inspired by among others Busenmeyer (2008) ${ }^{5}$ where a particular type of spending is expressed as a function of a matrix of control variables and the institutional variable of interest:

$$
\mathrm{Y}_{\mathrm{i}, \mathrm{t}}=\alpha_{\mathrm{i}}+\beta \mathrm{dec}_{\mathrm{i}, \mathrm{t}}+\delta \mathrm{X}_{\mathrm{i}, \mathrm{t}}+\varepsilon_{\mathrm{i}, \mathrm{t}}
$$

The dependent variable is the share of public physical and human capital investment spending in total public spending and the data are from the OECD National Accounts Database. The yearly observations are five-year moving averages in order to purge the data of cyclical effects. The control matrix consists of government size, calculated as total government tax revenue in relation to GDP from the OECD Revenue Statistics, and population (in 1 000s) from the same database. Both controls are expected to have a negative impact on the share of investment spending. As an economy develops and the public sector grows, governments have tended to spend a higher fraction on social spending. Also, the size of the population will have a negative impact on the ratio of capital to current spending if economies of scale are larger for investment spending.

Finding appropriate measures for fiscal decentralisation is challenging. For this reason several indicators are used. Previous studies on decentralisation frequently use SCG shares of total government expenditure and/or revenues. While these indicators have the advantage of longer cross-country time series availability, they only measure the funds that transit through local budgets which need not necessarily reflect the actual decision power of SCGs. This is why the three indicators of SCG share in total government expenditure, total revenue and tax revenue are here supplemented with the more recently developed OECD indicator on SCG tax autonomy. All indicators are taken from the OECD Fiscal Decentralisation Database. To avoid multi-collinearity, they are entered sequentially into four separate regressions. The final equations to be estimated are:

$$
\begin{aligned}
& \operatorname{INV}_{\mathrm{i}, \mathrm{t}}=\alpha_{\mathrm{i}}+\beta \text { GVTSIZE }_{\mathrm{i}, \mathrm{t}}+\delta \mathrm{POP}_{\mathrm{i}, \mathrm{t}}+\gamma \operatorname{EXPSHARE}_{\mathrm{i}, \mathrm{t}}+\varepsilon_{\mathrm{i}, \mathrm{t}} \\
& \mathrm{INV}_{\mathrm{i}, \mathrm{t}}=\alpha_{\mathrm{i}}+\beta \mathrm{GVTSIZE}_{\mathrm{i}, \mathrm{t}}+\delta \mathrm{POP}_{\mathrm{i}, \mathrm{t}}+\gamma \operatorname{REVSHARE}_{\mathrm{i}, \mathrm{t}}+\varepsilon_{\mathrm{i}, \mathrm{t}} \\
& \mathrm{INV}_{\mathrm{i}, \mathrm{t}}=\alpha_{\mathrm{i}}+\beta \mathrm{GVTSIZE}_{\mathrm{i}, \mathrm{t}}+\delta \mathrm{POP}_{\mathrm{i}, \mathrm{t}}+\gamma \operatorname{TAXREVSHARE}_{\mathrm{i}, \mathrm{t}}+\varepsilon_{\mathrm{i}, \mathrm{t}}
\end{aligned}
$$

5. However, contrary to his study, the lagged dependent variable is not included in our specification. This choice was made since institutional variables change slowly and therefore including their past values would absorb much of the variation in the data. 


$$
\mathrm{INV}_{\mathrm{i}, \mathrm{t}}=\alpha_{\mathrm{i}}+\beta \mathrm{GVTSIZE}_{\mathrm{i}, \mathrm{t}}+\delta \mathrm{POP}_{\mathrm{i}, \mathrm{t}}+\gamma \mathrm{TAXAUT}_{\mathrm{i}, \mathrm{t}}+\varepsilon_{\mathrm{i}, \mathrm{t}}
$$

An agnostic view is taken to the estimation technique and the pooled OLS estimator as well as the fixed effects estimator is used. Both country and time fixed effects are included, separately and simultaneously. Also, estimations are made on unbalanced panel datasets as well as time-averaged crosssectional datasets. The estimation period is from 1970 to 2010 which in reality means 1972 to 2008 for all other variables than the dependent variable because of time averaging. However, for most countries data on public investment only start around 1995. The tax autonomy variable is only available for the years 1995, 2002, 2005 and 2008; the time dimension for the estimations involving this variable is therefore reduced to only four observations for all variables. In addition to the baseline regressions, a number of extensions shed further light on the underlying relationship:

- $\quad$ Estimations were made for sub-samples of unitary and federal countries to ascertain differences in the effects of decentralisation between the two groups of countries.

- The jack-knife method is used to make sure that the results are robust to country outliers.

- In separate regressions, human capital spending and physical capital were separated. While much of human capital spending can be seen as an investment since effects of better schooling are likely to prevail throughout most of an individual's working life, the norm in the national accounts is to classify education spending as current expenditure.

\subsection{Education performance}

Better education performance improves the quality of the stock of human capital, which in turn affects economic output. Comparable cross-country data on education performance is available through the Education at a Glance dataset. This dataset includes data on inputs, access to and participation in education as well as on the organisation of the school sector. It is constructed from the PISA surveys that were conducted in 2000, 2003, 2006 and 2009 and answered by school children at age 15 and school administrations in all OECD countries.

Empirical work on education performance typically starts from an education production function where student achievement is modelled as a function of student characteristics, school resources and institutional variables. The average national PISA score is here taken as a measure of student achievement. ${ }^{6}$ Student characteristics (IND) are measured by the Economic, Social and Cultural Status (ESCS) indicator which is normalised and ranges between -1 and 1 . The literature consistently finds that academic results are positively and strongly correlated with a student's socio-economic background, and it is therefore expected that the estimated coefficient for this variable will be large and highly significant. Also, the ESCS indicator is highly correlated with GDP per capita. School resources (SCH) are captured by spending per student in secondary schooling in per cent of GDP. ${ }^{7}$ The literature is less conclusive on the effect of spending on student performance. These data are taken from the OECD Education at a Glance dataset.

6. $\quad$ Average score $=1 / 3$ score in mathematics $+1 / 3$ score in sciences $+1 / 3$ score in reading.

7. The ideal would be to have cumulative spending data for each student over a school career, but such data are not available. Secondary school spending is therefore considered a second-best option. Some studies add primary and secondary school expenditure but this is also a second-best option since current spending in primary schools can be very different from spending when the pupils answering the PISA questionnaires went to (pre) primary school. 
Several indicators are used to measure decentralisation (DEC): The institutional indicator of education decentralisation taken from the OECD Education at a Glance dataset shows the percentage of decisions related to the production of educational services taken at the non-central government level. Another indicator for education decentralisation is obtained the from the Classification of Functions of Government (COFOG) database. Finally, the four traditional indicators measuring fiscal decentralisation (SCG spending share; SCG revenue share; SCG tax revenue share and the indicator for SCG tax autonomy) are taken from the OECD Fiscal Network database. The final equation to be estimated is:

$$
\mathrm{PISA}_{\mathrm{i}, \mathrm{t}}=\alpha_{\mathrm{i}}+\beta \mathrm{IND}_{\mathrm{i}, \mathrm{t}}+\delta \mathrm{SCH}_{\mathrm{i}, \mathrm{t}}+\gamma \mathrm{DEC}_{\mathrm{i}, \mathrm{t}}+\varepsilon_{\mathrm{i}, \mathrm{t}}
$$

The econometric approach is analogous to the case of public investment. Both the pooled OLS estimator as well as the fixed effects estimator is used and for the latter both with country and time fixed effects used separately and simultaneously. Estimations are done both on unbalanced and balanced panel ${ }^{8}$ data as well as with cross-section data. However, using a balanced panel and particularly a cross-section time average imply a loss in the number of observations which is already quite small for some of the education estimations. While PISA surveys cover all OECD countries in the cross-country dimension, the time dimension is rather small with observations available only for four years. For most variables these years are 2000, 2003, 2006 and 2009. Unfortunately, neither the institutional indicator of education decentralisation nor the OECD tax autonomy indicator is available for exactly the same years. However, it is deemed justifiable not to make any corrections for this since the observations are not too far apart. Also, educational performance at the age of 15 is determined by educational inputs during the previous years of schooling and institutional variables typically do not vary much over time. ${ }^{9}$

The following extensions of the basic approach are made:

- Similar to the regressions on public spending composition, estimations are made for federal and unitary countries separately.

- The jack-knife method is again used to make sure that the results are robust to country outliers.

- The effects of decentralisation are differentiated according to whether decision-making power is given to the SCG administration or directly to the school. This allows evaluating potential differences in the effect of school autonomy versus decentralisation to lower levels of government. The latter is the sum of powers of all levels of government but the central government. Because this variable turns out not to be strongly correlated with school autonomy, both variables can enter simultaneously into the same regression.

- The effects of decentralisation are also estimated for different education functions. The Education at a Glance data distinguish between four types of functions: Organisation of instruction (instruction time, choice of textbooks, curriculum content and teaching methods), personnel management (hiring and firing of school director and teachers, teacher pay and responsibilities for and provision of in-service training), planning and structures (creating/closing down schools, school programme selection, defining course content and monitoring school performance) and

8. Countries with less than three observations in the time dimension for any one of the variables were excluded.

9. The first observation for the tax autonomy indicator is a special case as it is for 1995, which is some time earlier than that of the other variables, and the largest changes in the indicator happened between 1995 and 2002. To address this, a linear approximation between the two first observations for this variable is assumed meaning that the value in 2000 equals the value in 1995 to which is added 1/7th of the change between 1995 and 2002. 
financial resources (allocation of personnel and non-personnel budget, development of school improvement plans). Countries may rank differently according to which of the functions are considered, reflecting that education decentralisation can take many forms. Since there is a high correlation between the ranks, separate regressions are run.

\section{The impact of fiscal decentralisation on the composition of public spending}

\subsection{Fiscal decentralisation is associated with higher physical and human capital spending}

The results indicate that fiscal decentralisation is associated with a higher share of public resources devoted to physical and human capital spending. Table 1 presents results for the unbalanced panel specification using time fixed effects. All four decentralisation indicators yield positive and highly significant effects and the size of the effects are not negligible. Jack-knifing reveals that the results are robust to sample outliers. Using the pooled OLS estimator yields very similar results indicating that the data do not contain a strong time trend. Estimations in the cross-sectional specification (not presented) are all insignificant. Including country fixed effects also yields only insignificant estimates. This can occur when variables, such as institutional variables, vary across countries but change little over time and as a result the country fixed effects absorb all the variation in the data. As such, the fact that results with country fixed effects are insignificant does not discredit the other results. It is, however, unfortunate as country fixed effects are convenient tools to capture potential omitted variables. Control variables are mostly significant and with the expected sign.

The results are significant for both the federal and unitary sub-samples. The SCG revenue share sparks the most capital spending in unitary countries (while the tax autonomy indicator is less significant) whereas the effect of expenditure decentralisation and tax autonomy is larger in federal countries. There seems to be no intuitive reason for these differences in results and considering the smaller number of observations when working with sub-samples, one should be careful in placing too much faith in these results.

Most of the effect of decentralisation on the share of capital spending seems to be due to education spending. The effects of decentralisation on education spending alone are found to be significant which is in line with the literature and almost of the same magnitude as the effects on physical and human capital combined (Table 2). The evidence for a link between decentralisation and the share of public physical capital spending only is not compelling. Estimating an unbalanced panel specification including fixed effects still yields positive and significant coefficients for the SCG expenditure and tax revenue share, but the size of the effect is very modest (Table 3). The estimates for the two remaining decentralisation indicators are insignificant. Control variables remain mostly significant and with the expected sign. The effect of government size is larger than the size of the population and also more consistently significant. Again, the pooled OLS estimator yields similar results to the time fixed effects estimator, while using cross-sectional data yield again only insignificant results for all decentralisation variables, as does introducing country fixed effects. 
Table 1. Decentralisation and the share of public capital and education spending ${ }^{1}$

Unbalanced panel, time fixed effects, all OECD countries

\begin{tabular}{|c|c|c|c|c|c|c|c|c|c|c|c|c|}
\hline \multicolumn{13}{|c|}{ Dependent variable: Share of public physical and human capital spending } \\
\hline & \multicolumn{4}{|c|}{ All countries } & \multicolumn{4}{|c|}{ Federal countries } & \multicolumn{4}{|c|}{ Unitary countries } \\
\hline & Exp & Rev & Taxrev & Taxaut & Exp & Rev & Taxrev & Taxaut & Exp & Rev & Taxrev & Taxaut \\
\hline Government size & $-0.61^{\star \star \star}$ & $-0.60 * \star \star$ & $-0.61^{\star \star \star}$ & $-0.60 * \star \star$ & 0.01 & $-0.39 * \star \star$ & $-0.37^{\star \star \star}$ & 0.00 & $-0.58^{\star \star \star}$ & $-0.77^{\star \star \star}$ & $-0.77^{\star \star \star}$ & $-0.52^{\star \star \star}$ \\
\hline Population & $-0.03^{\star \star \star}$ & $-0.03^{\star \star \star}$ & $-0.03^{\star \star \star}$ & $-0.03^{\star \star}$ & $0.01 * * *$ & -0.04 & 0.02 & $0.02^{\star \star}$ & $-0.03^{\star \star}$ & -0.02 & -0.02 & -0.04 \\
\hline Decentralisation & $0.11^{\star \star *}$ & $0.11^{\star \star *}$ & $0.15^{\star \star \star}$ & $0.16^{\star \star}$ & $0.35^{\star \star *}$ & $0.13^{\star \star *}$ & $0.12^{\star \star \star}$ & $0.32^{\star \star \star}$ & $0.13^{\star \star \star}$ & $0.33^{\star \star \star}$ & $0.33^{\star \star \star}$ & $0.10^{*}$ \\
\hline$R^{2}$ adjusted & 0.42 & 0.40 & 0.44 & 0.44 & 0.85 & 0.61 & 0.60 & 0.85 & 0.45 & 0.53 & 0.53 & 0.36 \\
\hline No observation & 329 & 329 & 335 & 75 & 126 & 126 & 125 & 22 & 205 & 205 & 205 & 54 \\
\hline
\end{tabular}

Note: ${ }^{* \star *}$ means significance at the $1 \%$ level, ${ }^{* \star}$ means significance at $5 \%$ level and * means significance at $10 \%$ level.

1. Coefficients derive from linear multivariate regressions using time fixed effects. Decentralisation indicators are inserted sequentially into the equations in order to avoid multicollinearity.

Coefficients are point elasticities and therefore represent percentage point changes. E.g. 0.11 means that a $10 \%$ point decentralisation increase is associated with a capital spending share

increase of $1.1 \%$ points.

Source: OECD Fiscal Decentralisation Database; OECD National Accounts.

Table 2. Decentralisation and the share of education spending ${ }^{1}$

Unbalanced panel, time fixed effects, all OECD countries

\begin{tabular}{|c|c|c|c|c|c|c|c|c|c|c|c|c|}
\hline \multicolumn{13}{|c|}{ Dependent variable: Share of education spending } \\
\hline & \multicolumn{4}{|c|}{ All countries } & \multicolumn{4}{|c|}{ Federal countries } & \multicolumn{4}{|c|}{ Unitary countries } \\
\hline & Exp & Rev & Taxrev & Taxaut & Exp & Rev & Taxrev & Taxaut & Exp & Rev & Taxrev & Taxaut \\
\hline Government size & $-0.24^{\star \star \star}$ & $-0.24^{\star \star \star}$ & $-0.24^{\star \star \star}$ & $-0.19 * \star *$ & $0.40^{\star \star \star}$ & 0.15 & 0.10 & $0.25^{\star}$ & $-0.19 * \star *$ & $-0.30 * \star \star$ & $-0.29 * \star \star$ & 0.05 \\
\hline Population & $-0.01^{\star \star \star}$ & $-0.01^{\star \star \star}$ & $-0.01^{\star \star \star}$ & -0.01 & $0.02^{\star \star \star}$ & $0.01^{* *}$ & $0.01^{\star \star}$ & $0.02^{\star \star \star}$ & $-0.02^{\star *}$ & -0.03 & $-0.03^{\star \star \star}$ & $-0.03^{\star *}$ \\
\hline Decentralisation & $0.09 * * *$ & $0.11^{\star \star *}$ & $0.11^{\star \star \star}$ & $0.09 * *$ & $0.34^{\star \star \star}$ & $0.19^{\star \star \star *}$ & $0.15^{\star \star \star}$ & $0.23^{\star \star *}$ & $0.08^{\star \star *}$ & $0.19 * \star *$ & $0.18^{\star \star *}$ & $0.04^{\star * *}$ \\
\hline$R^{2}$ adjusted & 0.31 & 0.32 & 0.33 & 0.41 & 0.86 & 0.56 & 0.44 & 0.07 & 0.25 & 0.35 & 0.41 & 0.15 \\
\hline No observation & 329 & 329 & 335 & 80 & 124 & 124 & 123 & 27 & 205 & 205 & 212 & 54 \\
\hline
\end{tabular}

Note: ${ }^{* * *}$ means significance at the $1 \%$ level, ${ }^{* *}$ means significance at $5 \%$ level and ${ }^{*}$ means significance at $10 \%$ level.

1. Coefficients derive from linear multivariate regressions using time fixed effects. Decentralisation indicators are inserted alternatively into the equations in order to avoid multicollinearity. Coefficients are point elasticities and therefore represent percentage point changes. E.g. 0.11 means that a 10\% point decentralisation increase is associated with a capital spending share increase of $1.1 \%$ points.

Source: OECD Fiscal Decentralisation Database; OECD National Accounts. 
Table 3. Decentralisation and the share of public capital spending ${ }^{1}$

Unbalanced panel, time fixed effects, all OECD countries

\begin{tabular}{|c|c|c|c|c|c|c|c|c|c|c|c|c|}
\hline & \multicolumn{4}{|c|}{ All countries } & \multicolumn{4}{|c|}{ Federal countries } & \multicolumn{4}{|c|}{ Unitary countries } \\
\hline & Exp & Rev & Taxrev & Taxaut & Exp & Rev & Taxrev & Taxaut & Exp & Rev & Taxrev & Taxaut \\
\hline Government size & $-0.39 * \star \star$ & $-0.37^{\star \star \star}$ & $-0.53^{\star \star \star}$ & $-0.39 * \star \star$ & $-0.16^{\star \star \star}$ & $-0.25^{\star \star \star}$ & $-0.17^{\star \star *}$ & -0.16 & $-0.39 * \star \star$ & $-0.46^{\star \star \star}$ & $-0.58^{\star \star \star}$ & -0.33 \\
\hline Population & $-0.02^{\star \star \star}$ & $-0.02^{\star \star \star}$ & $-0.03^{\star \star *}$ & $-0.02^{\star \star *}$ & 0.00 & 0.00 & 0.00 & 0.00 & $-0.02^{\star}$ & -0.01 & $-0.03^{\star \star \star}$ & -0.02 \\
\hline Decentralisation & $0.02^{*}$ & 0.00 & $0.05^{\star \star \star}$ & 0.04 & 0.01 & $-0.03^{\star \star}$ & 0.00 & 0.00 & $0.07^{\star \star \star}$ & $0.14^{\star \star \star}$ & $0.19^{\star \star \star}$ & $0.04^{\star \star \star}$ \\
\hline$R^{2}$ adjusted & 0.39 & 0.38 & 0.54 & 0.41 & 0.34 & 0.37 & 0.34 & 0.07 & 0.45 & 0.47 & 0.55 & 0.38 \\
\hline No observations & 345 & 345 & 362 & 80 & 152 & 152 & 157 & 27 & 264 & 264 & 308 & 68 \\
\hline
\end{tabular}

Note: ${ }^{* \star *}$ means significance at the $1 \%$ level, ${ }^{\star *}$ means significance at $5 \%$ level and * means significance at $10 \%$ level.

1. Coefficients derive from linear multivariate regressions using time fixed effects. Decentralisation indicators are inserted alternatively into the equations in order to avoid multicollinearity.

Coefficients are point elasticities and therefore represent percentage point changes e.g. 0.11 means that a $10 \%$ point decentralisation increase is associated with a capital spending share increase of $1.1 \%$ points.

Source: OECD Fiscal Decentralisation Database; OECD National Accounts. 


\section{The impact of fiscal decentralisation on student performance}

\subsection{Education decentralisation improves student performance}

Virtually all specifications indicate a positive and significant relationship between the institutional indicator of education decentralisation and student performance. Again, jack-knifing does not alter much the significance of the results. A time fixed effects regression on unbalanced panel data yields an estimated coefficient of 0.4 (Table 4), meaning that a move from the least to the most decentralised country would increase the national PISA score by 28 points which is non-negligible considering that the variable is normalised around $500 .{ }^{10}$ A $10 \%$ point increase in education decentralisation improves the PISA ranking by around four points, corresponding to an improvement of the position by about four countries. The same results are obtained with the pooled OLS estimator. Estimations on balanced panel data as well as a crosssection time average result in equally significant and somewhat more sizeable effects. The coefficient is also positive for the education decentralisation indicator based on the Classification of Functions of Government (COFOG) data, but insignificant. The country coverage of this indicator is, however, very limited.

The traditional fiscal decentralisation indicators only yield insignificant results for the whole sample. This may seem surprising given the significantly positive impact of education decentralisation. However, while the indicator measuring education decentralisation is indeed positively related to the various fiscal decentralisation indicators, the correlation is not very strong. It ranges from 0.45 between the expenditure share of SCGs and education decentralisation to as low as 0.26 between tax autonomy and education decentralisation (Table 5). This illustrates the importance of using disaggregated variables to capture the effects of decentralisation in a particular policy area.

As was the case when looking at public investment, the effects are stronger for unitary countries. While in federal countries education decentralisation does not significantly affect student performance, the effect in unitary countries is highly significant and stronger than for the whole sample. Again, because of the small sample size one should refrain from putting too much faith in these results. The sample for federal countries is particularly small. Control variables in all regressions are mostly significant and have the expected sign. Unsurprisingly, the effect of students' socio-economic background is found to be particularly large and significant.

10. In 2009, the average value of national PISA scores ranged from 420 to 541, but most observations are comprised in a range from 480 to 520 . 
Table 4. Education decentralisation and PISA score ${ }^{1}$

Unbalanced panel, time fixed effects, all OECD countries

\begin{tabular}{|c|c|c|c|c|c|c|c|c|c|c|c|c|c|c|c|c|}
\hline \multicolumn{17}{|c|}{ Dependent variable: National PISA results } \\
\hline & \multicolumn{6}{|c|}{ All countries } & \multicolumn{5}{|c|}{ Federal countries } & \multicolumn{5}{|c|}{ Unitary countries } \\
\hline & $\begin{array}{l}\text { Educ } \\
\text { dec1 }^{2}\end{array}$ & $\begin{array}{l}\text { Educ } \\
\text { dec22 }\end{array}$ & Exp & Rev & Taxrev & Taxaut & $\begin{array}{l}\text { Educ } \\
\text { dec1 }^{2}\end{array}$ & Exp & Rev & Taxrev & Taxaut & $\begin{array}{l}\text { Educ } \\
\text { dec1 }^{2}\end{array}$ & Exp & Rev & Taxrev & Taxaut \\
\hline $\begin{array}{l}\text { Student } \\
\text { characteristics }\end{array}$ & $40.14^{\star \star \star}$ & 23.13 & $41.29^{\star \star \star}$ & $40.98^{\star \star \star}$ & $47.25^{\star \star \star}$ & $46.78^{\star \star \star}$ & $59.34^{\star \star \star}$ & $58.80^{\star \star \star}$ & $53.98^{\star \star \star}$ & $59.48^{\star \star \star}$ & $58.32^{\star \star \star}$ & $1.40^{\star \star}$ & $2.81^{\star \star \star}$ & 6.68 & $31.45^{\star \star \star}$ & $33.53^{*}$ \\
\hline $\begin{array}{l}\text { Education } \\
\text { spending/GDP }\end{array}$ & $1.42^{\star * \star}$ & -1.07 & $0.90^{*}$ & $0.87^{\star}$ & $1.19^{\star \star \star}$ & $1.31^{\star \star \star}$ & 1.02 & $1.36^{\star \star \star}$ & $1.03^{\star \star}$ & $0.95^{\star \star}$ & 1.00 & $1.41^{\star \star}$ & $1.42^{\star \star *}$ & -0.08 & $1.28^{*}$ & 2.17 \\
\hline Decentralisation & $0.40^{\star * \star}$ & 0.13 & 0.19 & 0.10 & 0.10 & 0.13 & 0.14 & $0.40^{*}$ & 0.26 & 0.14 & 0.31 & $0.65^{\star \star \star}$ & $0.64^{\star \star \star}$ & $0.72^{*}$ & 0.32 & 0.31 \\
\hline$R^{2}$ adjusted & 0.45 & 0.35 & 0.38 & 0.37 & 0.51 & 0.51 & 0.84 & 0.79 & 0.82 & 0.84 & 0.89 & 0.44 & 0.10 & 0.04 & 0.24 & 0.30 \\
\hline No observation & 84 & 41 & 100 & 100 & 115 & 32 & 25 & 33 & 34 & 39 & 10 & 59 & 66 & 67 & 76 & 22 \\
\hline
\end{tabular}

Note: ${ }^{* *}$ means significance at the $1 \%$ level, ** means significance at $5 \%$ level and * means significance at $10 \%$ level.

1. Coefficients derive from linear multivariate regressions using time fixed effects. Decentralisation indicators are inserted alternatively into the equations in order to avoid multicollinearity.

Coefficients are point elasticities and therefore represent percentage point changes. E.g. 0.40 means that a $10 \%$ point decentralisation increase is associated with an increase of 4 PISA points.

2. Educ dec1 is the institutional education decentralisation indicator from the OECD Education at a Glance data and educ dec2 is the education decentralisation indicator based on COFOG data.

Source: OECD Fiscal Decentralisation Database; OECD Education at a Glance Database; OECD National Accounts. 
Table 5. Education decentralisation versus fiscal decentralisation

Correlation matrix

\begin{tabular}{lc|c|c|c}
\hline & $\begin{array}{c}\text { Education } \\
\text { decentralisation }\end{array}$ & $\begin{array}{c}\text { Expenditure } \\
\text { decentralisation }\end{array}$ & $\begin{array}{c}\text { Revenue } \\
\text { decentralisation }\end{array}$ & Tax autonomy \\
\cline { 2 - 5 } Education decentralisation & 1 & 1 & & \\
Expenditure decentralisation & 0.45 & 0.76 & 1 & \\
Revenue decentralisation & 0.43 & 0.71 & 0.77 & 1 \\
\hline Tax autonomy & 0.26 & & & \\
\hline
\end{tabular}

Source: OECD Education at a Glance Database; OECD Fiscal Decentralisation Database.

\subsection{Both empowering schools and lower levels of government are beneficial}

Decentralisation to local governments and school autonomy can co-exist and countries may adopt some elements of both policies. Indeed one might expect that countries that have devolved many powers to local governments would have experienced pressure for providing even more autonomy to the school level. However, the data paint the opposite picture. There is a clear negative correlation between the extent of decentralisation to lower level governments and the extent of decentralisation to schools (school autonomy) (Figure 1).

Figure 1. Correlation between lower level government decentralisation and school autonomy

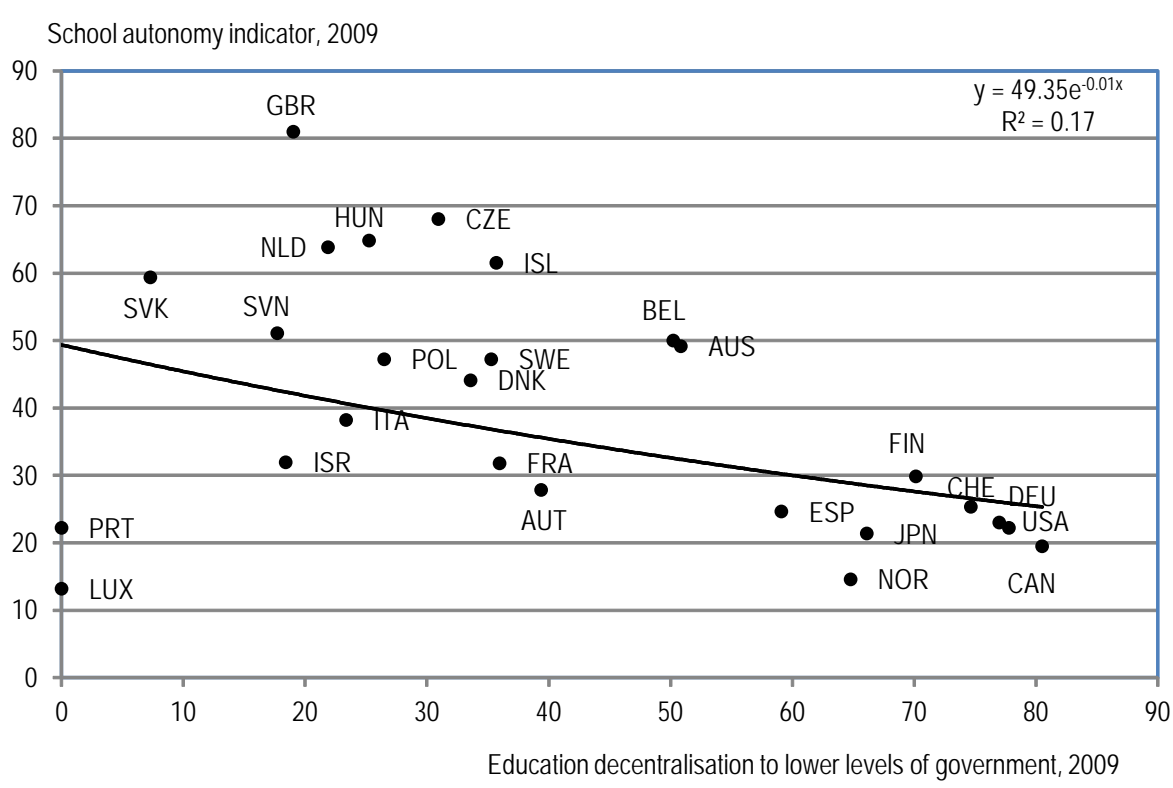

Source: OECD Education at a Glance Database.

Burki et al. (1999) note that the objectives behind the two kinds of decentralisation are usually different. Decentralisation of educational powers to local governments is generally undertaken as part of a larger, more general decentralisation reform, whereas school autonomy tends to be motivated by specific concerns about school performance. Indeed, the correlation matrix suggests that school autonomy is actually negatively correlated with economy-wide decentralisation, meaning that more decentralised countries tend to have less autonomous schools (Table 6). 
Table 6. Overall decentralisation, decentralisation to lower level of government and school autonomy Correlation matrix

\begin{tabular}{lc|c|c|c}
\hline & \multicolumn{2}{c|}{ Education decentralisation } & $\begin{array}{c}\text { All sector } \\
\text { decentralisation }\end{array}$ \\
\hline & $\begin{array}{c}\text { Aggregate } \\
\text { decentralisation }\end{array}$ & $\begin{array}{c}\text { Lower level } \\
\text { government }\end{array}$ & $\begin{array}{c}\text { School } \\
\text { autonomy }\end{array}$ & Tax revenue share \\
\cline { 2 - 5 } Education decentralisation & 1 & 1 & & \\
Lower level government & 0.67 & -0.52 & 1 & 1 \\
School autonomy & 0.28 & 0.77 & -0.43 & 1 \\
Tax revenue share & 0.47 & & & \\
\hline
\end{tabular}

Source: OECD Education at a Glance Database.

Even though countries may choose different approaches to education decentralisation, it appears to yield the same positive effects on performance. Dividing the overall decentralisation indicator in decentralisation to lower level governments and school autonomy, it is found that both types of decentralisation are equally beneficial for student results (Table 7). When federal and unitary countries are treated apart, the effect (i.e. the size of the coefficients) of empowering local governments is stronger than the effect of empowering schools for both sub-samples. On the contrary, when cross-section data as opposed to panel data with time-fixed effects are used, the results (not presented) suggest a somewhat larger effect from granting school autonomy as opposed to decentralisation to SCGs.

Table 7. Education decentralisation, school autonomy and PISA score ${ }^{1}$

Unbalanced panel, time fixed effects, all OECD countries

\begin{tabular}{|c|c|c|c|c|c|c|}
\hline \multicolumn{7}{|c|}{ Dependent variable: National PISA results } \\
\hline & \multicolumn{2}{|c|}{ All countries } & \multicolumn{2}{|c|}{ Federal countries } & \multicolumn{2}{|c|}{ Unitary countries } \\
\hline & $\begin{array}{c}\text { School } \\
\text { autonomy }\end{array}$ & SCG power & $\begin{array}{c}\text { School } \\
\text { autonomy }\end{array}$ & SCG power & $\begin{array}{c}\text { School } \\
\text { autonomy }\end{array}$ & SCG power \\
\hline $\begin{array}{l}\text { Student } \\
\text { characteristics }\end{array}$ & $37.81^{\star \star \star}$ & $37.81^{\star \star \star}$ & $54.13^{\star \star \star}$ & $54.13^{\star \star \star}$ & 13.42 & 13.42 \\
\hline $\begin{array}{l}\text { Education spending/ } \\
\text { GDP }\end{array}$ & $1.57^{\star \star *}$ & $1.57^{\star \star \star}$ & $1.39 *$ & $1.39 *$ & $1.30^{*}$ & $1.30 *$ \\
\hline Decentralisation & $0.51^{\star \star *}$ & $0.49^{\star \star \star}$ & 0.37 & $0.54^{\star \star}$ & $0.49 * \star \star$ & $0.76^{\star \star \star}$ \\
\hline$R^{2}$ adjusted & 0.48 & 0.48 & 0.84 & 0.84 & 0.40 & 0.40 \\
\hline No. observation & 83 & 83 & 25 & 25 & 58 & 58 \\
\hline
\end{tabular}

Note: ${ }^{\star \star \star}$ means significance at the $1 \%$ level, ${ }^{\star \star}$ means significance at $5 \%$ level and * means significance at $10 \%$ level.

1. Coefficients derive from linear multivariate regressions using time fixed effects. Decentralisation indicators are inserted simultaneously since they are not highly correlated. Coefficients are point elasticities and therefore represent percentage point changes. E.g. $=0.49$ means that a $10 \%$ point decentralisation increase is associated with a 4.9 PISA point increase.

Source: Fiscal Decentralisation Database.

\subsection{The size of effects varies according to the type of responsibility}

Finally, countries may also choose to devolve different functions within the domain of education. Education consists of a variety of functions such as financing, educational content and staff policy. On average, local units appear to have more power when it comes to organising instruction (e.g. class size, timetables, etc.) and in matters of financial resources. Power to decide overall pedagogical content of schools and monitoring their performance are to a greater extent kept at the central level. This is at least partially in line with Mons (2004) who notes that countries appear to have privileged the decentralisation of financing and day-to-day operational responsibility, leaving broader matters of curriculum at a more centralised level. 
It might be more advantageous to decentralise some decision powers than others. Although decentralisation is conducive to student performance regardless of the particular responsibility considered, the estimated coefficient using panel data is very small and close to insignificant for financial resources (Table 8). This is in line with the findings in OECD (2010). This might also be due to fewer observations for this sub-indicator. A more favourable finding is that decentralising the organisation of instruction is indeed found to yield the best result on PISA scores with a significant estimated coefficient often over twice the size as compared to the remaining three functions. The same conclusion holds when the sample is divided into the federal and unitary country sub-samples. 
Table 8. Education decentralisation according to function and PISA score ${ }^{1}$

Unbalanced panel, time fixed effects, all OECD countries

\begin{tabular}{|c|c|c|c|c|c|c|c|c|c|c|c|c|}
\hline \multicolumn{13}{|c|}{ Dependent variable: National PISA results } \\
\hline & \multicolumn{4}{|c|}{ All countries } & \multicolumn{4}{|c|}{ Federal countries } & \multicolumn{4}{|c|}{ Unitary countries } \\
\hline & Instruction & Personnel & Structure & Resources & Instruction & Personnel & Structure & Resources & Instruction & Personnel & Structure & Resources \\
\hline $\begin{array}{l}\text { Student } \\
\text { characteristics }\end{array}$ & $18.90^{\star \star}$ & 15.27 & $25.73^{\star \star \star}$ & $18.96^{*}$ & $50.74 * \star \star$ & $60.15^{\star \star \star}$ & 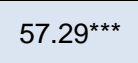 & $60.03^{* \star \star}$ & 20.59 & 2.04 & $31.85^{\star \star \star}$ & $23.63^{*}$ \\
\hline $\begin{array}{l}\text { Education spending } \\
\text { /GDP }\end{array}$ & -1.06 & -0.49 & -0.13 & -0.86 & 1.09 & 1.40 & 1.41 & 1.52 & 1.34 & $2.36^{*}$ & 1.79 & 1.67 \\
\hline Decentralisation & $0.50^{\star \star \star}$ & $0.24^{\star \star}$ & $0.21^{\star \star \star}$ & $0.20^{*}$ & 0.67 & 0.01 & 0.08 & 0.51 & $1.19^{\star \star \star}$ & $0.63^{\star \star \star}$ & $0.56^{\star \star \star}$ & $0.57^{\star \star \star}$ \\
\hline$R^{2}$ adjusted & 0.31 & 0.27 & 0.31 & 0.21 & 0.92 & 0.90 & 0.90 & 0.91 & 0.40 & 0.55 & 0.58 & 0.43 \\
\hline No observation & 45 & 49 & 50 & 39 & 9 & 9 & 9 & 9 & 22 & 22 & 31 & 31 \\
\hline
\end{tabular}

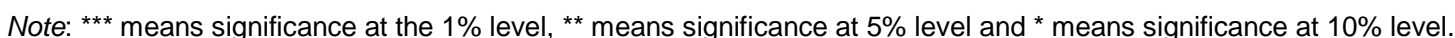

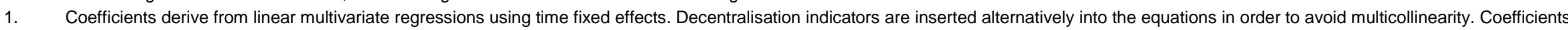
are point elasticities and therefore represent percentage point changes. E.g. 0.24 means that a $10 \%$ point decentralisation increase is associated with a 2.4 PISA point increase.

Source: Fiscal Decentralisation Database; OECD Education at a Glance Database. 


\section{BIBLIOGRAPHY}

Akai, N., et al. (2007), "Fiscal Decentralization and Educational Performance”, Conference Paper No. C07-001, University of California, Berkeley.

Arze del Granado, F., et al. (2005), "Fiscal Decentralization and The Functional Composition of Public Expenditures”, International Center for Public Policy (formerly the International Studies Program) Working Paper Series, AYSPS, GSU Paper 0501, Andrew Young School of Policy Studies, Georgia State University.

Aschauer, D. (1989), “Is Public Expenditure Productive?”, Journal of Monetary Economics, 23, pp. 177-200.

Barankay, I. and B. Lockwood (2006), "Decentralization and the Productive Efficiency of Government: Evidence from Swiss Cantons”, IZA Discussion Papers No. 2477, Institute for the Study of Labour (IZA).

Bénassy-Quéré, A., et al. (2007), “Tax and Public Input Competition”, Economic Policy, April.

Blöchliger H. and B. Égert (2013), Decentralisation and Economic Growth. Part 2: The Impact on Economic Activity, Productivity and Investment, OECD Working Papers on Fiscal Federalism, No. 16, OECD Publishing.

Burki, S.J., et al. (1999), “Beyond the Center - Decentralizing the State”, World Bank Publications.

Busemeyer, M. R. (2008), “The Impact of Fiscal Decentralisation on Education and Other Types of Spending”, Swiss Political Science Review, 14(3).

Égert, B., et al. (2009), "Infrastructure and Growth: Empirical Evidence”, OECD Economics Department Working Papers, No. 685, OECD Publishing.

Faguet, J-P. (2004), “Does Decentralisation Increase Government Responsiveness to Local Needs? Evidence from Bolivia”, Journal of Public Economics, No. 88.

Freinkman, L. and A. Plekhanov (2009), "Fiscal Decentralisation and the Quality of Public Services in Russian Regions”, European Bank for Reconstruction and Development Working Paper, No. 11.

Gonzalez Alegre, J. (2010), “Decentralization and the Composition of Public Expenditure in Spain”, Regional Studies, Vol. 44(8), pp. 1067-1083.

Grisorio, M.J. and F. Prota (2011), "The Impact of Fiscal Decentralization on the Composition of Public Expenditure: Panel Data Evidence from Italy”, Societa italiana degli economisti, 52.

Habibi, N., et al. (2003), "Decentralization and Human Development in Argentina”, Journal of Human Development, Vol. 4, No. 1.

Kappeler, A. and T. Välilä (2007), “Composition of Public Investment and Fiscal Federalism: Panel Data Evidence from Europe”, Economic and Financial Report 2007/02, European Investment Bank. 
Keen, M. and M. Marchand (1997), “Fiscal competition and the pattern of public spending”, Journal of Public Economics, 66, pp. 33-53.

OECD (2010), PISA 2009 Results: What Makes a School Successful? Resources, Policies and Practices, Vol. IV, OECD Publishing.

Rodriguez-Pose, A. and A. Krojier (2009), "Fiscal Decentralization and Economic Growth in Central and Eastern Europe”, Growth and Change, Vol. 40, No. 3.

Sutherland, D. and R. Price (2007), "Linkages between Performance and Institutions in the Primary and Secondary Education Sector”, OECD Economics Department Working Papers, No. 558, OECD Publishing. 